\title{
HUBUNGAN JENIS KELAMIN DAN PEMINATAN DENGAN KELULUSAN UJI KOMPETENSI MAHASISWA NERS STIKES JENDERAL ACHMAD YANI YOGYAKARTA
}

\author{
Deby Zulkarnain Rahadian Syah, Sujono Riyadi \\ Dosen Keperawatan Stikes Jenderal Achmad Yani Yogyakarta \\ Email: deby.ayani14@gmail.com
}

\begin{abstract}
Competence test is a process of measuring the knowledge, skill, and behavior of learners in Mid-Level Expert in Nursing or Nurse Profession at the end of their study period to reach the competency standard of graduates a job competency standard. Graduation of competency test nurse student to $68,61 \%$, indicating that there is $31,39 \%$ which not yet competent. The aim of research is to analyze the relationship of gender and student interest with graduation of competency test of nurse students. The research type is descriptive correlation with cross sectional approach. The research was conducted at Stikes General Achmad Yani Yogyakarta. The results showed that men slightly greater the number of graduates of nurse competence test than women. 11 competent men and 10 competent women. The statistical test results obtained p-value 1.00 shows no relationship between sex with the passing of competence test nurse. This study also resulted that the Nurse student program is not related to the passing of nurse competence test with p-value 0.976 . Therefore, both male and female ners should still study the theory in every phase.
\end{abstract}

Keywords: Competency test, gender, specialization

\begin{abstract}
Abstrak: Uji kompetensi merupakan proses pengukuran pengetahuan, keterampilan, dan perilaku peserta didik pada Program Studi Keperawatan baik D3 maupun S1 ners di akhir masa studinya untuk mencapai standar kompetensi lulusan yang memenuhi standar kompetensi kerja. Kelulusan uji kompetensi ners sebesar 68,61 \%, menunjukkan bahwa ada $31,39 \%$ yang belum kompeten. Tujuan penelitian adalah menganalisis hubungan jenis kelamin dan peminatan mahasiswa dengan kelulusan uji kompetensi mahasiswa ners. Jenis penelitian deskriptif korelasi dengan pendekatan cross sectional. Penelitian dilakukan di Stikes Jenderal Achmad Yani Yogyakarta. Hasil penelitian menunjukkan bahwa laki-laki sedikit lebih besar jumlah kelulusan uji kompetensi perawat daripada perempuan. Laki-laki 11 orang yang kompeten dan perempuan 10 orang yang kompeten. Hasil uji statistik didapatkan nilai $p$-value 1,00 menunjukkan tidak ada hubungan antara jenis kelamin dengan kelulusan uji kompetensi perawat. Penelitian ini juga menghasilkan bahwa program peminatan mahasiswa Ners tidak berhubungan dengan kelulusan uji kompetensi perawat dengan nilai p-value 0,976. Oleh karena itu mahasiswa ners baik laki-laki maupun perempuan tetap harus belajar teori dalam setiap stase.
\end{abstract}

Kata kunci: Uji kompetensi, jenis kelamin, peminatan

\section{PENDAHULUAN}

Penekanan pengembangan dan pembinaan pendidikan tinggi keperawatan di masa depan lebih diarahkan pada upaya meningkatkan mutu pendidikan, sehingga lulusan benar-benar menunjukkan sikap profesional, menguasai ilmu pengetahuan keperawatan dalam kadar yang memadai, serta menguasai keterampilan profesional keperawatan. Pihak-pihak yang mengelola pendidikan tinggi keperawatan dan pihak-pihak yang berkepentingan diharapkan 
memahami arti dan makna pendidikan keperawatan sebagai pendidikan profesi serta melaksanakan pendidikan secara keseluruhan (Nursalam, 2012).

$$
\text { Undang-Undang Sisdiknas }
$$

Nomor 20 tahun 2003 Bab II pasal 3 menyatakan bahwa pendidikan tidak hanya melahirkan dan mencetak manusia yang pintar, namun juga memiliki kepribadian yang mantap dan mandiri, serta tanggung jawab kemasyarakatan dan kebangsaan. Kompetensi seorang perawat adalah sesuatu yang ditampilkan secara menyeluruh oleh seorang perawat dalam memberikan pelayanan professional kepada klien, mencakup pengetahuan, keterampilan, dan pertimbangan yang dipersyaratkan dalam situasi praktik (Nursalam, 2012). Uji kompetensi adalah proses pengukuran pengetahuan, keterampilan, dan perilaku peserta didik pada perguruan tinggi yang menyelenggarakan Program Studi Keperawatan. Mahasiswa keperawatan baik D3 maupun S1 ners pada akhir masa studinya diwajibkan untuk mengikuti uji kompetensi nasional. Uji kompetensi ditujukan untuk mencapai standar kompetensi lulusan yang memenuhi standar kompetensi kerja (UU Keperawatan, 2014).

Penelitian yang dilakukan oleh Abdillah (2016) tentang faktor yang mempengaruhi kelulusan uji kompetensi ners di Stikes Ngudia Husada Madura menjelaskan bahwa ada hubungan antara penyelenggaraan try out dengan kelulusan mahasiswa ners. Faktor indeks prestasi kumulatif, gaya belajar mahasiswa juga memiliki hubungan dengan kelulusan ners.

Hasil studi pendahuluan yang dilakukan pada mahasiswa Stikes Jenderal Achmad Yani Yogyakarta pada tanggal 31 Maret 2017 menggunakan data sekunder bahwa tingkat kelulusan mahasiswa ners dalam mengikuti uji kompetensi nasional sesuai SK nomor
902/Puk-Nas/XI/2016 November 2016 masih 68,61\%. Masih ada 31,39\% mahasiswa ners yang belum lulus uji kompetensi nasional.

Penelitian ini bertujuan menganalisis hubungan jenis kelamin dan peminatan mahasiswa dengan kelulusan uji kompetensi mahasiswa ners di Stikes Jenderal Achmad Yani Yogyakarta.

\section{METODE}

Design penelitian ini adalah deskriptif komparasi dengan pendekatan cross-sectional. Penelitian dilakukan di Stikes Jenderal Achmad Yani Yogyakarta pada bulan Mei-Agustus 2017. Populasinya adalah mahasiswa Ners Stikes Jenderal Achmad Yani Yogyakarta yang mengikuti Uji Kompetensi Nasional. Sampel sebanyak 30 responden yang dipilih secara simple random sampling. Analisis statistik menggunakan chi square.

\section{HASIL DAN PEMBAHASAN}

\section{Hasil Penelitian}

Tabel 1. Distribusi Frekuensi Responden Berdasarkan Jenis Kelamin

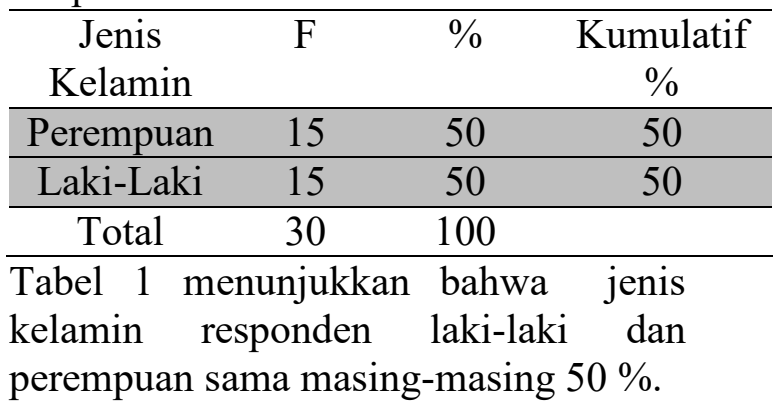

Tabel 2. Distribusi Frekwensi Responden Berdasarkan Peminatan Dalam Profesi Ners

\begin{tabular}{lccc}
\hline Peminatan & F & $\%$ & $\begin{array}{c}\text { Kumulatif } \\
\%\end{array}$ \\
\hline IGD & 14 & 46,7 & 46,7 \\
\hline OK & 12 & 40,0 & 86,7 \\
\hline HD & 2 & 6,7 & 93,3 \\
\hline ICU & 2 & 6,7 & 100 \\
\hline Total & 30 & 100 & \\
\hline
\end{tabular}


Tabel 2 menunjukkan bahwa peminatan responden setelah selesai stase profesi sebagian besar memilih IGD sebesar $46,7 \%$. Peminatan yang sedikit adalah HD dan ICU sebesar 6,7\%.

Tabel 3. Distribusi Frekwensi Responden Berdasarkan Kelulusan Uji Kompetensi

\begin{tabular}{lccc}
\hline Hasil Ukom & F & $\%$ & $\begin{array}{c}\text { Kumulatif } \\
\%\end{array}$ \\
\hline Kompeten & 21 & 70 & 70 \\
\hline $\begin{array}{l}\text { Tidak } \\
\text { Kompeten }\end{array}$ & 9 & 30 & 100 \\
\hline Total & 30 & 100 & \\
\hline
\end{tabular}

Tabel 3 menunjukkan bahwa hasil uji kompetensi sebagaian besar kompeten sebanyak $70 \%$.

Tabel 4. Tabulasi Silang Jenis Kelamin dengan Kelulusan Uji Kompetensi

\begin{tabular}{|c|c|c|c|c|}
\hline \multirow{2}{*}{$\begin{array}{c}\text { Jenis } \\
\text { Kelamin }\end{array}$} & \multicolumn{2}{|c|}{ Ukom } & \multirow[t]{2}{*}{ Total } & \multirow[t]{2}{*}{$\mathrm{p}$} \\
\hline & $\begin{array}{c}\text { Kompet } \\
\text { en }\end{array}$ & $\begin{array}{c}\text { Tidak } \\
\text { Kompeten }\end{array}$ & & \\
\hline $\begin{array}{c}\text { Perempua } \\
n\end{array}$ & 10 & 5 & 15 & 1,00 \\
\hline Laki-Laki & 11 & 4 & 15 & \\
\hline Total & 21 & 9 & 30 & \\
\hline
\end{tabular}

Tabel 4 menunjukkan bahwa uji

kompetensi perawat laki-laki sedikit lebih banyak jumlah kelulusannya dengan perempuan, laki-laki sebanyak 11 orang dan perempuan sebanyak 10 orang. Hasil uji statistik didapatkan nilai $p$-value 1,00 yang artinya tidak ada hubungan antara jenis kelamin dengan kelulusan uji kompetensi perawat.

Tabel 5. Tabulasi Silang Jenis Peminatan dengan Kelulusan Uji Kompetensi

\begin{tabular}{ccccc}
\hline Peminatan & \multicolumn{2}{c}{ Ukom } & Total & $p$ \\
\cline { 2 - 4 } & $\begin{array}{c}\text { Kompet } \\
\text { en }\end{array}$ & $\begin{array}{c}\text { Tidak } \\
\text { Kompeten }\end{array}$ & & \\
\hline IGD & 9 & 5 & 14 & 0,976 \\
\hline OK & 8 & 4 & 12 & \\
\hline HD & 2 & 0 & 2 \\
\hline ICU & 2 & 0 & 2 & \\
\hline Total & 21 & 9 & 30 & \\
\hline
\end{tabular}

Tabel 5 menunjukkan bahwa peminatan mahasiswa Ners pada pilihan IGD lebih banyak lulus uji kompetensi perawat sejumlah 9 orang. Hasil uji statistik didapatkan nilai p-value 0,976 yang artinya tidak ada hubungan antara program peminatan dengan kelulusan uji kompetensi perawat.

\section{Pembahasan}

Penelitian ini memberi gambaran peserta uji kompetensi nasional laki-laki dan perempuan memiliki jumlah yang sama dan analisis statistik menunjukkan tidak ada perbedaan jenis kelamin terhadap kelulusan uji kompetensi nasional. Hasil penelitian ini menunjukkan bahwa lakilaki dan perempuan memiliki motivasi, semangat yang sama untuk mendapatkan sertifikat kompetensi agar dapat digunakan sebagai salah satu persyaratan registrasi sebagai perawat.

Peminatan mahasiswa ners Stikes Jenderal Achmad Yani Yogyakarta sebagian besar memilih IGD sebesar 46,7\%.Peminatan adalah salah satu sks dalam program studi profesi ners. Mahasiswa profesi ners wajib mengikuti peminatan yang mempunyai 4 sks dengan berbagai pilihan seperti IGD, ICU, Bedah, dan Hemodialisa (HD). Pelaksanaan peminatan selama 4 minggu yang dicapai melalui tugas tertentu sesuai jalur peminatan yang diambil (Kurikulum PSIK, 2010-2014).

Hasil penelitian menunjukkan bahwa uji kompetensi nasional mahasiswa ners sebagian besar lulus dengan prediket kompeten sebanyak $70 \%$. Persentase yang dicapai tersebut memberikan umpan balik kepada perguruan tinggi terhadap pelaksanaan proses pembelajaran karena dengan uji kompetensi berarti telah dilakukan proses pengukuran pengetahuan, keterampilan, dan perilaku peserta didik pada perguruan tinggi yang 
menyelenggarakan Program Studi Keperawatan. Uji kompetensi juga merupakan amanah dari UndangUndang Keperawatan nomor 38 tahun 2014 yang menyebutkan bahwa pada akhir masa pendidikan harus mengikuti uji kompetensi nasional yang bertujuan untuk mencapai standar kompetensi lulusan yang memenuhi standar kompetensi kerja.

Materi uji kompetensi disusun mengacu kepada standar kompetensi yang tercantum dalam standar profesi. Materi Uji Kompetensi dikembangkan dan disusun oleh divisi standarisasi MTKI yang berkoordinasi dengan Dirjen Dikti Kementerian Ristekdikti dan LPUK serta Tim Ad-hock di MTKI yang berasal dari masing-masing organisasi profesi. Uji kompetensi memberikan harapan baru bagi dunia perawat sebagai momentum peningkatan kualitas pendidikan keperawatan di Indonesia (BPPSDMK, 2013)

Metode yang digunakan dalam uji kompetensi lulusan tenaga kesehatan bentuk Multiple Choice Questions (MCQ) berdasarkan Blue Print masingmasing profesi. Blue print perawat terdiri dari 9 bidang keilmuan yaitu keperawatan maternitas (3-15\%) asumsi soal 18 soal; keperawatan anak (5-15\%) 18 soal; Keperawatan Gawat darurat (610\%) 14 soal; Keperawatan medikal bedah $(25-35 \%)$ soal 54 soal; keperawatan Jiwa (5- 15\%) 18 soal ; Keperawatan keluarga (5- 15\%) 18; Keperawatan Gerontik (4-8\%) 10 soal; Keperawatan Komunitas (4-8\%) 10 soal; Manajemen Keperawatan (5-15\%) 18 soal jadi keseluruhan 180 soal setiap soalnya harus diselesaikan dalam 1 menit. Materi uji kompetensi disusun mengacu kepada standar kompetensi yang tercantum dalam standar profesi (BPPSDMK, 2013).

Hasil penelitian menunjukkan bahwa kelulusan uji kompetensi perawat laki-laki sedikit lebih banyak daripada perempuan, laki-laki sejumlah 11 orang kompeten dan perempuan sejumlah 10 orang yang kompeten. Hasil uji statistik disimpulkan tidak ada hubungan antara jenis kelamin dengan kelulusan uji kompetensi perawat. Hasil penelitian ini sejalan dengan penelitian Yanti \& Warsito (2013) yang menjelaskan bahwa tidak ada hubungan antara jenis kelamin dengan kualitas dokumentasi (p-value 0,659). Ilyas (2001) menjelaskan bahwa jenis kelamin dapat memberikan dorongan yang berbeda, laki-laki memiliki dorongan lebih besar daripada perempuan karena tanggung jawab lakilaki lebih besar.

Hasil penelitian ini juga menunjukkan bahwa kelulusan uji kompetensi perawat dengan peminatan IGD lebih banyak lulus dibanding peminatan lainnya. Hasil uji statistik didapatkan kesimpulan tidak ada hubungan antara program peminatan dengan kelulusan uji kompetensi perawat. Program pemintan di Stikes Jenderal Achmad Yani Yogyakarta merupakan program tambahan sebanyak 4 SKS bagi mahasiswa yang sudah menyelesaikan semua stase dalam profesi ners. Dengan program peminatan diharapkan mahasiswa ners lebih terampil dan terarah pada salah satu aspek peminatan dalam pemberian asuhan keperawatan kepada pasien. Namun demikian, jika merujuk pada kurikulum AIPNI (Asosiasi Institusi Profesi Ners Indonesia) untuk program peminatan tidak diwajibkan.

\section{KESIMPULAN}

\section{Kesimpulan}

Tidak ada hubungan antara jenis kelamin dan program peminatan dengan kelulusan uji kompetensi nasional perawat di Program Profesi Ners Stikes Jenderal Achmad Yani Yogyakarta. 


\section{Saran}

Mahasiswa Program Profesi Ners Stikes Jenderal Achmad Yani Yogyakarta baik laki-laki maupun perempuan tetap harus belajar teori dalam setiap stase. Program sudi ners dapat menganalisis faktor lain yang mendukung kelulusan uji kompetensi nasional perawat pada penelitian lanjutan.

\section{DAFTAR PUSTAKA}

Abdillah, A. (2016). Faktor-faktor yang memengaruhi kelulusan uji kompetensi ners Indonesia. JPAP. Vol 2 No 2. 373-380

Badan Pengembangan dan Pemberdayaan Sumber daya Manusia Kesehatan, (2013). Uji Kompetensi Bidan dan Perawat. http://bppsdmk.kemkes.go.id/pusk atmutu/index.php/pustanserdik/ko ntenberita/94

Hungu. 2007. Demografi Kesehatan Indonesia. Jakarta: Penerbit Grasindo.

Ilyas. 2001. Teori, Penilaian dan Penelitian Kinerja. Cetakan Kedua. Jakarta: Pusat Kajian Ekonomi Kesehatan FKM-UI.

Kurikulum PSIK, (2010-2014). Kurikulum Program Studi Ilmu Keperawatan Stikes Jenderal Achmad Yani Yogyakarta. Yogyakarta

Nursalam. (2012). Manajermen Keperawatan: Aplikasi dalam Praktik Keperawatan Profesional. Jakarta: Salemba Medika

UU Keperawatan (2014). Praktik Keperawatan. Nomor 38. Jakarta

UU Nomor 20 Tahun 2003 Tentang Sistem Pendidikan Nasional. Jakarta

Yanti dan Warsito, (2013). Hubungan karakteristik perawat, motivasi, dan supervisi dengan kualitas dokumentasi proses asuhan keperawatan. Jurnal Manajemen Keperawatan. Volume 1 Nomor 2 2013.107-114 